KEBIJAKAN REDAKSIONAL MEDIA LOKAL DI YOGYAKARTA

DALAM PEMBERITAAN COVID-19

(Studi Kasus Kebijakan Redaksional di Harian Jogja dan Tribun Dalam

Pemberitaan Covid-19))

\title{
LOCAL MEDIA EDITORIAL POLICY IN YOGYAKARTA IN NEWS OF COVID-19 \\ (Case Study Editorial Policy in Harian Jogja and Tribun Jogja in News Of Covid-19)
}

\author{
Andreas Tri Pamungkas', Olivia Lewi Pramesti \\ ${ }^{1}$,Universitas Amikom Yogyakarta \\ Jl Ring Road Utara, Sleman, Yogyakarta \\ ${ }^{2}$ Universitas Atma Jaya Yogyakarta \\ Jl. Babarsari No. 44, Sleman, Yogyakarta \\ e-mail: andreas.pamungkas@amikom.ac.id', olivia.lewi@uajy.ac.id ${ }^{2}$
}

(Diterima: 23-02-2021; Direvisi: 10-06-2021; Disetujui terbit: 25-06-2021)

\begin{abstract}
Abstrak
Media massa lokal berperan dalam menyebarluaskan informasi mengenai Covid-19. Pemberitaan Covid-19 masuk dalam kebijakan redaksional media karena mengandung nilai berita penting (significance). Kebijakan redaksional penting untuk diteliti karena persoalan Covid-19 ini memengaruhi seluruh aspek kehidupan dalam masyarakat dari politik, ekonomi, sosial, dan budaya. Penelitian ini akan melihat kebijakan redaksional dari media lokal di Yogyakarta, Harian Jogja dan Tribun Jogja dalam pemberitaan Covid-19. Peneliti ingin melihat bagaimana media lokal berperan menjalankan fungsinya sebagai sumber informasi yang mendidik serta menyejahterakan masyarakat melalui kebijakan redaksionalnya. Kebijakan redaksional akan dilihat melalui pendekatan story selection Gans. Metode dalam penelitian ini adalah studi kasus dengan melakukan wawancara mendalam pada redaksi. Kebijakan redaksional dilihat dari periode Maret 2021 hingga April 2021. Hasil penelitian menunjukkan kedua media lokal memprioritaskan agenda pencegahan Covid-19. Harian Jogja dan Tribun Jogja melihat pemerintah daerah tidak memiliki kesiapan dalam mitigasi pandemi, sehingga membuat kedua redaksi media lokal tersebut memiliki penajaman yang berbeda di masing- masing aspek story selection Gans, yaitu (1) source considerations, (2) substantive considerations, (3) product considerations, (4) value considerations, (5) commercial considerations, (6) audiens considerations, dan (7) political consideration.
\end{abstract}

Kata kunci: covid-19, kebijakan redaksional, media lokal, pendekatan Gans

\begin{abstract}
Local mass media play a role in disseminating information about Covid-19. The news of Covid-19 is included in the editorial policy of the media because it contains important news value (significance). Editorial policies are important to research because the Covid-19 problem affects all aspects of life in society from politics, economy, social and culture. This study will look at the editorial policies of local media in Yogyakarta, Jogja Daily and Tribun Jogja in reporting on Covid-19. Researchers want to see how local media play an active role as a source of information that educates and improves the welfare of the community through its editorial policies. The editorial policy will be seen through the Gans story selection approach. The method in this research is a case study by conducting in-depth interviews with the editor. The editorial policy is seen from the period March 2021 to April 2021. The results show that the two local media prioritize the Covid-19 prevention agenda. Daily Jogja and Tribun Jogja saw that the local government did not have readiness in mitigating the pandemic, thus making the two local media editors have different sharpening in each aspect of choosing Gans stories, namely (1) source considerations, (2) substantive considerations, (3) product considerations, (4) value considerations, (5) commercial considerations, (6) audience considerations, and (7) political considerations.
\end{abstract}

Keywords: covid-19, editorial policy, local media, Gans theory. 


\section{PENDAHULUAN}

Pemberitaan Covid-19 di Indonesia ramai diperbincangkan media sejak Maret 2021. Perbincangan di media ini dipicu dengan hadirnya pasien pertama di Indonesia. Sejak kemunculan pasien pertama, pemberitaan media masih terus berlanjut dengan menghadirkan berbagai sudut pandang (angle) baik dari sisi politik, ekonomi, sosial, serta budaya. Variasi angle ini tak luput karena Covid-19 merupakan pandemi di seluruh dunia dan berpengaruh pada semua aspek kehidupan masyarakat termasuk di Indonesia. Dari sisi jurnalistik, pemberitaan Covid-19 memiliki nilai berita penting (significance) dan berdampak (impact). Oleh karena itu, pemberitaan Covid-19 tidak pernah lepas dari perbincangan media.

Di awal pemberitaannya, pemberitaan di media massa diwarnai dengan dinamika. Salah satu berita yang diperdebatkan adalah ketika keluarnya identitas pasien secara vulgar, lengkap dengan alamat serta visual tempat tinggal pasien. Dari berita tersebut, Dewan Pers bahkan sampai mengeluarkan imbauan agar media memerhatikan kepentingan publik yang lebih luas dalam memuat berita atau laporan Covid-19. Dalam pernyataannya, Dewan Pers mengharap agar media tidak berlebihan, sehingga melupakan prinsip-prinsip kode etik. Media juga diminta tidak menyebut nama, foto, tempat tinggal karena menyangkut hak privasi, serta tidak menimbulkan kepanikan masyarakat (Dewan Pers, 2020).

Perdebatan atas identitas pasien Covid19 pada media-media di Indonesia masuk dalam ranah kebijakan redaksional media masing-masing. Kebijakan redaksional, menurut Abdullah (dalam Wibisono, Pawito, dan Astuti, 2019) adalah sikap "politik" media dalam memandang suatu permasalahan juga aturan keredaksian dan kewartawanan yang diterapkan. Berdasar kutipan tersebut, aturan keredaksian berkaitan dengan keputusan internal redaksi masing-masing media. Keputusan internal ini menjadi hak bagi media yang bersangkutan untuk melayani masyarakat. Hak ini merupakan bagian dalam kebebasan pers dalam menjalankan tugasnya. Kebebasan pers sendiri menurut Merril (dalam Sudirman dan Miming, 2015) adalah suatu kondisi riil yang memungkinkan para pekerja pers bisa memilih, menentukan, dan mengerjakan tugas sesuai keinginan mereka. Prinsip kebebasan pers ini harus mengacu pada UU No.40 Tahun 1999 tentang Pers dan Kode Etik Jurnalistik.

Kebijakan redaksional atas sebuah isu dalam masyarakat dipengaruhi berbagai faktor. Menurut Shoemaker (2014), terdapat lima faktor yang memengaruhi isi media, individu media, rutinitas organisasi, organisasi, ekstramedia, dan ideologi media. Kelima faktor ini akan berpengaruh pada banyak hal, seperti seperti pemilihan angle (sudut pandang berita) penempatan halaman (terutama di media cetak), pemilihan diksi, serta pemilihan narasumber. Hal ini senada dengan pendapat Abdullah (dalam dalam Wibisono, Pawito, dan Astuti, 2019) yang menyatakan bahwa dalam kebijakan redaksional, redaksi memilih kriteria berita, tulisan, kata, ungkapan, yang boleh dan tidak boleh dimuat untuk dipublikasikan sesuai visi misi media.

Kebijakan redaksional pun berkaitan erat dengan agenda setting media. Buluamang (2020) menyatakan agenda setting berkaitan dengan penempatan isuisu oleh media dengan isu publik. Pengaturan agenda didasarkan pentingnya prioritas perhatian dalam isi media terhadap 
isu dan peristiwa, memberitakan isu yang menonjol dan pengetahuan sesuai agenda publik dan dampaknya pada opini publik. Amali (2017) menambahkan dalam agenda setting, media massa menyaring berita, artikel, tulisan yang akan disiarkan, setiap kejadian atau isu diberi bobot tertentu dengan panjang peyajian (ruang dalam surat kabar atau waktu televisi dan radio) dan cara penonjolan (ukuran judul pada surat kabar atau waktu televisi dan radio).

Keputusan pemilihan isu melalui proses seleksi dalam redaksi menjadi bagian dalam fungsi pers untuk mencerdaskan masyarakat. Pers memiliki tanggung jawab untuk mencari tahu mengapa dan apa yang harus dilakukan, jika publik tidak memiliki informasi. Masyarakat menjadi bagian utama dalam tujuan kegiatan jurnalistik. Kesetiaan pada warga negara ini kemudian bermakna apa yang disebut dengan independensi jurnalistik. (Kovach \& Rosenstiel, 2014).

Dalam konteks negara demokrasi, pers menjadi jembatan antara kekuasaan dan masyarakat. Lestahalu (2015) menyatakan keberadaan pers penting dalam mengembangkan kehidupan demokrasi. Hal tersebut nampak dalam berbagai fungsi pers, yakni 1) fungsi pendidikan; 2) fungsi kontrol sosial salah satunya sebagai anjing penjaga (watchdog) di mana pers berfungsi mengawasi pemerintah, legislatif, dan yudikatif; serta 3) fungsi agenda setting di mana pers harus bisa memilih isu mana yang akan ditampilkan dan isu mana yang akan diabaikan. Keputusan isu ini akan memengaruhi persepsi dalam masyarakat. Di Indonesia sendiri, fungsi pers juga tercantum dalam UU No. 40 Tahun 1999 Tentang Pers di mana pers memiliki peranan untuk memenuhi hak masyarakat untuk mengetahui, mengembangkan pendapat umum berdasarkan informasi yang tepat, akurat dan benar, melakukan pengawasan kritik dan saran terhadap halhal berkaitan dengan kepentingan umum, serta memperjuangkan keadilan dan kebenaran.

Penelitian ini akan melihat kebijakan redaksional media lokal dalam isu Covid19. Media lokal menarik untuk diteliti karena media lokal memiliki kontribusi dalam menegakkan demokrasi. William (2006) menyatakan bahwa media lokal memiliki peran penting dalam demokrasi lokal yakni sebagai investigator dan pemberi informasi bagi masyarakat. Media lokal memberikan informasi tentang pemerintah lokal dan komunitas lokal yang dapat memberikan pilihan bagi masyarakat untuk memilih informasi yang berpengaruh pada lingkungan terdekat mereka. Erat kaitannya dengan peristiwa Covid-19, kebijakan redaksional media lokal menarik untuk dilihat. Peristiwa Covid-19 memiliki dampak yang berbeda pada daerah satu dengan yang lainnya. Perbedaan dampak ini pun akan turut berpengaruh pada aspek lain di daerah tersebut. Melalui media lokal, masyarakat lokal bisa memperoleh informasi yang dekat dengan dirinya. Pilihan informasi soal Covid-19 di media lokal membantu masyarakat lokal untuk bisa bertindak yang sesuai kebutuhan mereka.

Mengingat pentingnya keberadaan media lokal atas penyebaran informasi atas Covid-19, penting sekali untuk melihat kebijakan redaksional lokal di daerah. Kebijakan redaksional media lokal ini akan membantu peneliti untuk melihat sikap "politik" redaksi atas persoalan Covid-19 di daerahnya. Kebijakan redaksional pun dapat melihat sudut pandang media lokal atas aspek-aspek kehidupan masyarakat lokal yang berdampak karena peristiwa Covid-19. 
Penelitian ini akan melihat kebijakan redaksional dari dua media lokal di Yogyakarta yakni Harian Jogja dan Tribun Jogja. Berdasar riset awal yang dilakukan peneliti pada salah satu redaktur pelaksana koran lokal Yogyakarta, Harian Jogja, Nugroho Nurcahyo pada awal Januari 2020, media lokal justru menghadapi kondisi yang sebaliknya ketika mencoba mengikuti agenda pemberitaan Covid-19. Media lokal kesulitan untuk mengakses informasi penyebaran Covid-19 dari dinas terkait serta tidak mendapatkan nama identitas pasien. Kesulitan media lokal dalam memperoleh informasi soal Covid-19 membuat masyarakat pun tidak puas atas informasi yang disajikan. Hal ini terbukti dengan munculnya gerakan dari Jaringan Masyarakat Sipil di Yogyakarta pada 17 Maret 2020 yang mendesak pemerintah Yogyakarta untuk transparan dalam memberikan informasi penanganan virus, jumlah orang dalam pantauan (ODP), pasien dalam pengawasan (PDP), pasien suspect, dan pasien positif virus Corona dengan gambaran wilayah tinggal.

Berdasar riset awal tersebut, peneliti berasumsi bahwa kondisi yang dihadapi media lokal dalam awal pemberitaan Covid-19 akan memengaruhi kebijakan redaksional mereka. Bila merujuk pada pernyataan Shoemaker (2014) mengenai salah satu faktor yang memengaruhi isi media, yakni ekstramedia, redaksi akan kesulitan mendapatkan perspektif dari pihak luar khususnya pemerintah terkait kebijakan Covid-19 di Yogyakarta. Di sisi lain, faktor ekstramedia ini penting sebagai bentuk peliputan cover both sides pada kasus ini. Pemerintah pun menjadi aktor penting dalam kasus ini karena Covid-19 berkaitan dengan kebijakan pemerintah dalam penanganan Covid-19.
Ali (et all, 2020) menyatakan bahwa masyarakat akan mencari informasi soal Covid-19 dari sumber informasi berbeda dan terpercaya yang ditentukan oleh karateristik sosiodemografi mereka. Hal ini akan membantu penyebaran informasi Covid-19 di masyarakat untuk meningkatkan pengetahuan dan keyakinan mereka tentang pandemi ini. Zhao (et all, 2020) pun menambahkan bahwa masyarakat akan mempercayai informasi dari media dari sumber-sumber profesional dan terpercaya yang berdampak pada perilaku mereka. Hal ini disebabkan karena banyak informasi yang tidak benar soal Covid-19. Berdasar kutipan ini, peneliti berasumsi bahwa penyebaran informasi Covid-19 oleh media di daerah sangat ditentukan oleh sumber-sumber informasi yang terpercaya, salah satunya pemerintah agar masyarakat bisa bertindak dengan benar.

Berdasar riset awal tersebut, peneliti berasumsi bahwa kondisi yang dihadapi media lokal dalam awal pemberitaan Covid-19 akan memengaruhi kebijakan redaksional mereka. Bila merujuk pada pernyataan Shoemaker (2014) mengenai salah satu faktor yang memengaruhi isi media, yakni ekstramedia, redaksi akan kesulitan mendapatkan perspektif dari pihak luar khususnya pemerintah terkait kebijakan Covid-19 di Yogyakarta. Di sisi lain, faktor ekstramedia ini penting sebagai bentuk peliputan cover both sides pada kasus ini. Pemerintah pun menjadi aktor penting dalam kasus ini karena Covid-19 berkaitan dengan kebijakan pemerintah dalam penanganan Covid-19.

Ali (et all, 2020) menyatakan bahwa masyarakat akan mencari informasi soal Covid-19 dari sumber informasi berbeda dan terpercaya yang ditentukan oleh karateristik sosiodemografi mereka. Hal ini 
akan membantu penyebaran informasi Covid-19 di masyarakat untuk meningkatkan pengetahuan dan keyakinan mereka tentang pandemi ini. Zhao (et all, 2020) pun menambahkan bahwa masyarakat akan mempercayai informasi dari media dari sumber-sumber profesional dan terpercaya yang berdampak pada perilaku mereka. Hal ini disebabkan karena banyak informasi yang tidak benar soal Covid-19. Berdasar kutipan ini, peneliti berasumsi bahwa penyebaran informasi Covid-19 oleh media di daerah sangat ditentukan oleh sumber-sumber informasi yang terpercaya, salah satunya pemerintah agar masyarakat bisa bertindak dengan benar.

Penelitian soal kebijakan redaksional isu Covid-19 pernah dilakukan di media Radar Banjarmasin. Penelitian kebijakan redaksional di Radar Banjarmasin menggunakan konsep Shoemaker dan Vos dengan membedah kebijakan redaksi melalui lima faktor yakni individual, organisasional, rutinitas media, esktra media, dan ideologi (Hanief et al., 2021). Kebaruan penelitian ini dibandingkan penelitian sebelumnya terletak pada pisau analisisnya. Penelitian ini pendekatan Gans soal story selection.

Reese (2009) menyatakan bahwa pendekatan Gans mengenai story selection adalah dari perspektif sosiologi. Perspektif sosiologi sendiri dilihat dari struktur dan kultur yang ada di masyarakat. Gans melihat media dari sisi masyarakat di mana media menjadi solusi atas persoalan di masyarakat. Gans mengemukakan bahwa dalam membuat berita, jurnalis merespon terlebih dahulu dari struktur sosial. Oleh karena itu, pandangan redaksi atas sebuah persoalan yang tertuang dalam berita bukankah pandangan jurnalis, editor, publisher, melainkan dari keseluruhan proses yang terlibat dalam organisasi. Pendekatan Gans dipilih oleh peneliti karena persoalan Covid-19 merupakan persoalan bersama yang melibatkan masyarakat luas. Melalui perspektif Gans, peneliti hendak melihat bagaimana media turut melakukan advokasi untuk merespon yang terjadi di antara akar rumput dan aktor pemerintahan dalam pencegahan meluasnya Covid-19.

\section{LANDASAN TEORI}

\section{Media Lokal dan Agenda Setting}

Menurut McQuail (dalam Hamer, 2006) media lokal berhubungan dengan aspek geografis spesifik yang menyediakan kebutuhan (dalam hal ini infomasi, komentar) bagi pembaca lokal dan sarana mengekspresikan kebudayaan lokal. WahlJorgensen (2006) menyatakan bahwa media lokal melalui keputusan editor membuka forum terbuka untuk perbincangan publik atas informasi yang diberikan. Editor pun sebagai gatekeepers tidak bisa menolak tugas mereka atas perbincangan publik. Media lokal memainkan peran untuk membentuk diskusi bagi komunitas lokal. Oleh karena itu, editor memilih agenda lokal yang sesuai dengan komunitas lokal mereka.

Wahl-Jorgensen (2006) berpendapat bahwa tulisan di media lokal merupakan barometer dari pendapat lokal dan merepresentasikan gagasan mereka. Tulisan media lokal bertujuan untuk memotivasi masyarakat lokal untuk terlibat dalam isu lokal. Tulisan tersebut membantu masyarakat memahami isu lokal yang tidak mereka ketahui sebelumnya. Dalam menentukan isu lokal pun, editor akan mempertimbangkan isu mana yang tengah diperbincangkan oleh publik lokal. Inilah yang disebut dengan agenda setting media. 
Agenda setting media menurut Coleman, et al (2009) adalah proses media massa mempresentasikan isu berkala dan dekat publik di mana isu tersebut lebih penting dibandingkan isu lain. Dalam agenda setting media menenkankan sebuah isu yang berpengaruh pada sikap publik. Agenda setting pun tidak hanya berlaku untuk media nasional, melainkan juga media lokal. McCombs \& Marcus (2011) menyatakan bahwa agenda lokal media dipengaruhi oleh komunitas lokal. Media lokal biasanya membandingkan cakupan masalah lokal dengan surat kabar lokal dan nasional yang sesuai dengan karakteristik demografis mereka.

\section{Kebijakan Redaksional Media}

Gans (2004) menyatakan pengertian jurnalisme dalam konsep media merupakan disiplin empiris seperti halnya sosiologi. Gans memandang berita sebagai cermin hierarki masyarakat dan bangsa, dalam hal ini termasuk aktor pemerintahan, serta bagaimana dampak bagi banyak orang dan signifikansi untuk masa lalu dan masa mendatang. Namun pada kenyataannya Gans mencatat media dihadapkan pada keterbatasan ruang, waktu, ketersediaan informasi, dan akses narasumber, sehingga harus memilih yang sebenarnya hanya bagian kecil dari sebuah cerita (Gans, 2004).

Gans (2004) memaparkan soal aspekaspek dalam story selection. Pertama, source considerations terdiri dari source availability dan source suitability. Source availability ditentukan oleh dorongan narasumber saat berhubungan dengan media, akses narasumber terhadap kekuasaan (power), kemampuan/keahlian narasumber dalam memasok berita, dan kedekatan narasumber dengan media baik secara geografis maupun sosial. Sedangkan source suitability ditentukan oleh kelayakan informasi yang diberikan narasumber waktu lalu, produktivitas pasokan informasi, tingkat kepercayaan yang dibangun narasumber, posisi/jabatan narasumber, dan artikulasi narasumber.

Kedua, substantive consideration dilihat dari aspek penting dan menarik. Ketiga, product considerations, merujuk pada tipe dan format berita yang disesuaikan tipe media dan audiens. Keempat, value considerations,berkaitan dengan nila jurnalisme seperti nilai objektivitas berita. Nilai objektivitas berita ini di antaranya meliputi kefaktualan berita (kebenaran, relevansi, dan informasi), dan imparsialitas (keseimbangan dan netralitas). Kelima, commercial considerations berkaitan dengan perampingan biaya pemilihan dan produksi berita, serta peningkatan pendapatan perusahaan melalui perhatian audiens dan iklan. Keenam, audiens considerations, bahwa informasi harus menarik dan memberikan ketersediaan informasi yang padat untuk audiens, misalnya penggunaan data. Ketujuh, political considerations, bahwa informasi mengandung desakan dari kelompok tertentu berdasarkan kekuasaan dan kepentingan mereka.

\section{METODE PENELITIAN}

Penelitian ini berupaya untuk mengungkap kebijakan redaksi media lokal dalam pemberitaan Covid-19. Metodologi dalam penelitian ini adalah studi kasus yang memungkinkan peneliti untuk mengeksplorasi dan mengelaborasi temuan penelitian secara mendalam. Peneliti akan melihat kebijakan redaksional media lokal yang berbasis cetak dan memiliki platform media daring. SimilarWeb, situs pemeringkatan daring menjadi dasar dalam penentuan subjek dan objek penelitian. 
Sesuai kriteria peneliti, terdapat empat media lokal di Yogyakarta yang memenuhi syarat, yaitu jogja.tribunews.com, harianjogja.com. krjogja.com, dan radarjogja.jawapos.com. Berdasarkan peringkat SmiliarWeb per 15 Februari 2020, berikut ranking dari empat media tersebut : jogja.tribunews.com (total visits 9,11 juta), harianjogja.com (1,89 juta). krjogja.com (868,4 ribu), dan radarjogja.co (126,24 ribu). Peneliti menentukan peringkat satu dan dua sebagai obyek penelitian dengan dasar media daring tersebut banyak diakses pembaca.

Data primer dalam penelitian ini diperoleh melakukan wawancara mendalam dengan Nugroho Nurcahyo, Redaktur Pelaksana Harian Jogja dan Hendy Kurniawan, Manajer Produksi Tribun Jogja. Alasan pemilihan kedua informan tersebut berdasar pada keterlibatan langsung dari informan dalam penetuan kebijakan redaksi pemberitan Covid 19. Selain wawancara, peneliti menggunakan studi pustaka untuk data sekundernya.

\section{HASIL PENELITIAN DAN PEMBAHASAN \\ Source Consideration}

Ketersediaan sumber menjadi persoalan yang sama dialami oleh Tribun Jogja dan Harian Jogja. Media lokal mendapatkan momentum untuk mengikuti pemberitaan Covid-19 begitu Presiden Jokowi mengumumkan dua pasien positif di Depok, Jawa Barat, namun kedua media lokal tersebut terkendala dalam mengakses narasumber di level pemerintah daerah setempat. Narasumber dari instansi pemerintahan atau pihak terkait yang berwenang di lingkungan Pemerintah Daerah DIY terkesan tertutup, sementara
Satuan Gugus Tugas (Satgas) Covid-19 di daerah juga belum terbentuk. (Nurcahyo, Redaktur Pelaksana Harian Jogja, wawancara, 15 Januari 2020).

"Redaksi kesulitan untuk
mendapatkan narasumber,
sementara Pemda tidak mau
dianggap tidak punya mitigasiatau
pencegahan penyebaran Covid-19.
Pemda tertutup takut kesiapan
dinilai kurang. Saat narasumber
seperti kepala bidang, kepala dinas
dikonfirmassi kadang tidak mau
memberi keterangan sepatah dua
kata, "Tanya ke [RSUP] Sardjito
saja." (Nurcahyo, wawancara,
2020).

Redaksi Harian Jogja menilai Pemda DIY tergolong lambat dalam melakukan penanganan Covid-19. Penilaian ini mendasar saat Presiden Jokowi merilis pasien positif, Pemerintah Daerah DIY tidak kunjung melakukan kampanye pencegahan Covid-19, tetapi justru menunjukkan sikap sebaliknya dengan tetap menggelar kegiatan- kegiatan pemerintahan yang menimbulkan kerumunan. Di tengah kondisi tersebut, pernyataan Sri Sultan Hamengku Buwono $\mathrm{X}$ dinilai kontraproduktif. Sultan yang sekaligus Gubernur DIY tersebut dalam keterangan Senin 9 Maret, menyatakan bahwa Yogyakarta masih aman dan siap dikunjungi wisatawan. Sultan adalah sumber yang terpercaya. Pernyataannya sebagaimana konsep Gans (2004) dalam merumuskan source dapat menekankan rencana pemerintah. 'Sabda' Sultan pun dianggap dapat memberikan informasi tanpa menguras banyak waktu, karena 
dua atribusinya yang melekat tersebut sekaligus dapat memberikan persuasi tentang protokol kesehatan kepada masyarakat. Namun dalam waktu yang bersamaan, source consideration memungkinkan melakukan evaluasi terhadap sumber, karena memiliki tujuan yang berbeda. Sejak awal, kedua redaksi media lokal tersebut memiliki agenda pencegahan Covid-19 dengan tujuan mengurangi resiko penyebaran.

Redaksi Tribun Jogja menegaskan Sultan dalam pemberitaan Covid-19 tidak dapat diposisikan sebagai sumber utama, karena pernyataanya yang tidak selalu sejalan dengan agenda redaksi tersebut (Hendy Kurniawan, Manager Produksi Tribun Jogja, wawancara, 20 Januari 2020). Di tengah kesulitan mengakses sumber, kedua redaksi dalam waktu yang terbatas mempertimbangkan aspek realibility yang menjadi bagian source consideration. Realibility adalah penggunaan sumber terpercaya, namun informasinya hanya memerlukan pemeriksaan paling sedikit (Gans, 2004). Kedua redaksi memutuskan menggunakan narasumber pakar. Tribun Jogja dan Harian Jogja mengaku tidak ada pilihan lain. Pemberitaan lebih mengandalkan pernyataan- pernyataan dari pakar untuk memberikan pemahaman kepada masyarakat mengenai bahaya Covid-19 (Hendy Kurniawan, Manager Produksi Tribun Jogja, wawancara, 20 Januari 2020). Redaksi percaya bahwa ketika ada warga yang positif di ibu kota, Covid-19 akan cepat menyebar ke berbagai daerah lainnya, termasuk di wilayah Yogyakarta. Hal ini karena mobilitas masyarakat dari Yogyakarta ke Jakarta atau sebaliknya terbilang tinggi (Nugroho Nurcahyo, Redatur Pelaksana
Harian Jogja, wawancara, 15 Januari 2020).

"Sultan kadang kita jadikan angle utama kadang enggak, tergantung yang disampaikan. Ketika pernyataannya kontrapoduktif tidak menjadi angle utama, kita pilih yang sejalan dengan agenda media kami. Dari pernyataan tersebut (Yogyakarta amar) terkesan meremehkan bahaya Covid-19. Perekonomian diutamakan, isu kesehatan dikesampingkan." (Nurcahyo, wawancara, 2020).

"Pernyataan Sutan bukan dipakai acuan utama. Pernyataan Sultan yang sifatnya teknis data atau kondisi lapangan jarang terpakai. Pernyataannya sekadar untuk melengkapi berita saja." (Kurniawan, wawancara, 2020).

Sumber dari pejabat daerah baru dapat diandalkan ketika Pemerintah Daerah DIY mengeluarkan data real time pasien Covid19 melalui laman corona.jogjaprov.go.id yang di dalamnya terdapat data orang dalam pemantauan (ODP), pasien dalam pengawasan (PDP), pasien suspect, dan pasien positif Covid-19 dengan gambaran wilayah tempat tinggal. Data ini dikeluarkan tidak berselang lama setelah ada desakan dari Jaringan Masyarakat Sipil pada tanggal 17 Maret 2020 agar pemerintah daerah dapat transparan menyampaikan data penyebaran Covid-19.

\section{Subtantive Consideration}

Pada aspek pertama yang berbicara rank in governmental and other hierarchies, beberapa hal telah sedikit disinggung di subbab sebelumnya terkait 
dengan source consideration Gubernur DIY yang telah dieliminasi sebagai sumber terpercaya. Gans (2004) menekankan semakin tinggi posisi hierarki aktor di pemerintahan semakin banyak aktivitasnya yang muncul di media, begitu pula aktivitas Sultan beserta jajarannya yang tidak peduli dengan protokol kesehatan Covid-19 meyakinkan redaksi untuk tidak memihaknya dan menjadi dasar untuk menentukan mana berita yang penting dan menarik. Hal tersebut semata- mata juga karena berkaitan dengan aspek substantive consideration lainnya yang kurang lebih menyangkut dampak bagi kepentingan bangsa dan kesejahteraan dengan adanya pandemi, juga dengan prediksi- prediksi ancaman pandemi yang meluas dapat menambah semakin banyaknya warga yang terpapar Covid-19. Dalam aspek significance for the past and future, media tidak ingin mengabaikan peristiwaperistiwa yang di masa mendatang bakal menimbulkan resiko besar (Gans, 2004). Sementara redaksi Harian Jogja di lapangan melihat kondisi masyarakat yang tidak percaya dengan bahaya Covid-19. Masyarakat saat itu meyakini bahwa Covid19 hanyalah sebuah rekayasa, belum lagi banyaknya informasi hoaks yang bermunculan di tengah pandemi. Oleh karenanya, Harian Jogja memutuskan untuk memproduksi berita yang isinya bersifat "menakut- nakuti" bahaya dan meluasnya penyebaran Covid-19, sehingga masyarakat bisa belajar dan bekerja dari rumah. Ketidakpercayaan warga terhadap Covid-19 bisa menambah jumlah warga positif, sementara rumah sakit di Yogyakarta daya tampungnya terbatas.

"Agenda kami di awal menakutinakuti bahaya Covid. Itu kami lakukan agar Covid-19 tidak diremehkan.
Penyebaran sangat cepat, sementara kapasitas rumah sakit terbatas." (Nurcahyo, wawancara, 2020).

Salah satu berita "menakut- nakuti" itu dibuat berdasarkan data laman corona.jogjaprov.go.id. Berita tersebut berjudul : '1 Kecamatan 200 lebih, ODP Covid-19 di Kota Jogja Melonjak Drastis'. Redaksi menilai berita tersebut dapat menghadirkan rasa takut kepada warga, meski kemudian ditemukan kesalahan dalam berita tersebut. Redaksi kemudian mengoreksinya dengan judul : 'Sudah Mencapai 200 lebih, ODP Covid-19 di Jogja Melonjak Drastis'. Harian Jogja juga menyampaikan permintaan maaf : 'Kami Keliru, Kami Minta Maaf, dan Bantu Kami.” Kekeliuran berita tersebut karena ada kesalahan baca di data real time. Data di laman corona.jogjaprov.go.id memungkinkan terbaca sebagai akumulasi ODP, padahal sesungguhnya data tersebut menyajikan penomoran ODP yang tercatat di seluruh DIY, misalnya saja ada data di Kecamatan Umbulharjo ODP-270 yang dimaksud adalah bukan menunjukan ada 270 ODP di kecamatan tersebut, melainkan ada ODP ke 270 yang tercatat di DIY.

Berita penting didasarkan pada aspek substantive consideration terkait dampak yang dapat diakibatkan. Isu Pembatasan Sosial Berskala Besar (PSBB) menjadi fokus kedua redaksi. Harian Jogja pada mulanya mengesampingkan aspek stabilitas perekonomian di daerah, meski di kemudian hari redaksi berkesimpulan agar isu pemulihan perekonomian di daerah agar menjadi hal yang penting untuk diulas. Sementara Tribun Jogja sejak awal lebih memilih untuk memaparkan konsekuensi baik buruk penerapan PSBB. Subtantive consideration juga menaruh perhatian pada interesting stories atau cerita- cerita 
humanis yang menarik. Cerita menarik digunakan karena alasan berita penting sering kali "buruk" dan harus diimbangi dengan cerita yang menarik, diantaranya laporan ringan people stories dan human interest stories (Gans, 2004).

People stories menampilkan orang biasa berada dalam situasi yang tidak biasa. Tribun Jogja memfokuskan people stories, seperti aksi- aksi solidaritas, mulai dari membagikan makanan, sayuran, dan lain sebagainya. Berita- berita tersebut dinilai dapat menjadi penyegar dengan harapan dapat memunculkan rasa solidaritas antar warga (Hendy Kurniawan, Manager Produksi Tribun Jogja, wawancara, 20 Januari 2020).

Di sisi lain, cerita- cerita menarik human interest memungkinkan media untuk membangkitkan simpati audiens dari cerita orang- orang dalam menjalani pengalaman, baik kisah pilu ataupun heroik (Gans, 2004).

Tribun Jogja mengambil peluang tersebut dengan tujuan agar masyarakat tersadar untuk patuh pada protokol kesehatan, seperti kisah pemulasaraan atau perawatan jenazah, cerita pengubur jenazah yang bercerita kesedihan keluarga pasien dibawa ke liang kubur.

Harian Jogja melihat kisah people stories dan human interest untuk menyentuh sisi manusiawi di tengah beritaberita 'menakutkan' atau buruk, diantaranya kisah penolakan tenaga medis di tempat tinggalnya, padahal mereka telah bertaruh nyawa merawat pasien Covid-19, sebagaimana Gans mengkategorikan kisah human interest yang bertindak heroik dalam bencana mengidentifikasikan tindakan kepahlawanan.

\section{Product Considerations}

Tribun Jogja menerapkan gaya penulisan micro, people dan non problematic. Penulisan judul orang menurut Sumargo (dalam Pamungkas, 2016) adalah dekat dengan unsur people atau pendekatan sosok atau tokoh. Gaya penulisan ini bertujuan untuk mendekatkan Tribun Jogja dengan mereka yang setiap hari berinteraksi. Sementara cara mengupas ulasan informasinya bak sebuah drama yang ditulis dari fakta lapangan. Jika koran lain sekadar menuliskan kronologi berita kejadian kecelakaanya, tetapi Tribun Jogja sampai dalam mengangkat kisah dibalik korban atau keluarganya.

Meski demikian dalam pemberitaan Covid-19, tidak semua peristiwa yang berkaitan dapat diterjemahkan dalam konsep mikro people. Hal tersebut karena menyangkut kekuatan profil narasumber dari sisi korban. Redaksi Tribun Jogja urung mengangkat cerita dari korban/ pasien positif, kecuali pasien yang bersangkutan mendeklarasikan diri. Redaksi berasumsi korban akan defensif ketika hendak diwawancara, karena stigma negatif yang melekat pada korban Covid-19 (Hendy Kurniawan, Manager Produksi Tribun Jogja, wawancara, 20 Januari 2020). Sementara itu, Harian Jogja Harian Jogja memiliki rubrik khusus "Waspada Corona" untuk membahas serba- serbi Covid-19. Rubrik tersebut semula bernama 'Buka Mata' yang mengulas berita mendalam secara tematik.

\section{Value Condiserations}

Harian Jogja melakukan liputan kolaborasi bersama banyak media. Kolaborasi itu dilakukan dengan jurnalis kompas.id, voaindonesia.com, gatra, tirto.id, dan idntimes.com. Berdasarkan rilis Tim Kolaborasi Jurnalis, jumlah media 
yang bargabung terus bertambah sejak awal kali seri pertama dipublikasikan serentak pada 16 April 2010. Media televisi CNN Indonesia juga bergabung dalam liputan kolaborasi tersebut.

Teknis liputan kolaborasi jurnalis ini dikerjakan secara bersama dengan kesamaan isu dan waktu penayangan yang dilakukan secara serentak, sementara format liputannya bisa dikategorikan sebagai liputan investigasi karena sifatnya yang mengungkap data.

Pada seri pertama liputan, kolaborasi membahas sejumlah persoalan dalam pendataan kematian di DIY selama periode pandemi. Pada seri pertama, Harian Jogja memberikan judul 'COVID-19 di DIY: Mereka yang Hilang Tapi Tak Terdata, sementara milik Kompas.id berjudul 'Jejak Sengkarut Data Korona di Yogyakarta. Adapula yang terbit di Voaindonesia.com berjudul 'Simpang Siur Data Pasien Corona', kemudian liputan Tirto.id memberikan judul 'Mereka yang Mati Tak Tercatat \& Tanpa Dites Saat Pandemi COVID-19'. Tulisan lainnya seperti milik Idntimes.com berjudul: Data Kematian COVID-19 di DIY Amburadul, PDP Meninggal Tak Tercatat.

Liputan kolaborasi ini dinilai cukup menguntungkan, karena media lebih mudah mendapatkan akses informasi.

"Wartawan di lapangan terbatas akses datanya. Kolaborasi dianggap lebih menguntungkan narasumber, karena menghindari data atau pernyataannya diplintir (tidak sesuai dengan apa yang dikatakan atau dilebih- lebihkan)." (Nurcahyo, wawancara, 2020).

Dalam teknis liputannya, tim kolaborasi menyepakati data liputan dapat dibagikan, tidak terkecuali bagi wartawan yang tidak berada di lokasi wawancara.
Wartawan yang meliput telah menyampaikan ke narasumber bahwa hasil rekaman wawancara akan digunakan oleh tim kolaborasi. Menurut Nugroho Nurcahyo, data mentah tersebut menjadi ranah masing- masing redaksi untuk diolah atau memilih kutipan mana yang akan digunakan.

Langkah ini tidak dilakukan oleh Tribun Jogja. Dalam mengejar obyektivitas tersebut, redaksi mengakui sempat mengalami kepanikan, karena psikologi awak redaksi saat awal pandemi mengalami ketakutan berlebih karena peliputan yang dilakukan harus berhadapan dengan 'musuh' yang tidak terlihat yakni Covid-19. Di sisi lain, isu kesehatan dinilai satu dari sekian materi pemberitaan yang rumit dan acap kali menyesatkan, misalnya saja komentar antar satu tenaga medis dengan pakar lainnya dapat berbeda. Kondisi tersebut acap kali membuat redaksi mengeluarkan kebijakan yang sifatnya sporadis alias tanpa berpikir panjang dan mengurangi daya kritis (Hendy Kurniawan, Manager Produksi Tribun Jogja, wawancara, 20 Januari 2020).

Redaksi kemudian memilih mengangkat laporan- laporan ringan yang menyentuh empati audiens. Liputanliputan yang lebih dekat dengan faktor substantive consideration seperti pada subbab sebelumnya tersebut diharap dapat membangkitkan empati masyarakat, sehingga tersadar diri untuk patuh pada protokol kesehatan.

\section{Audiens Considerations}

Pertimbangan ini sebenarnya berkaitan dengan value consideration, karena liputan kolaborasi yang dilakukan Harian Jogja otomatis di satu sisi ingin memberitahukan kepada audiens bahwa banyak fakta yang tidak terungkap terkait 
penaganan Covid-19 oleh Pemerintah Daerah DIY. Dalam penjabaran lainnya audiens considerations juga berkaitan dengan pertimbangan melindungi audiens agar tidak terlalu marah atau menjadi ketakutan, sehingga dapat membuat audiens mengalami kecemasan, seperti syok dan panik (Gans, 2004). Kepanikan dalam pemberitaan Covid-19 seperti yang telah dibahas pada bab sebelumnya dipicu dengan penyebutan lengkap identitas pasien. Dalam rangka untuk turut melakukan pencegahan penyebaran Covid19, Harian Jogja membuat kebijakan untuk melakukan penulusuran terhadap keberadaan pasien Covid-19. Secara teknis, redaksi tidak menyebut nama pasiennya karena menyangkut hak privasi, kecuali pasien bersedia menyebutkan identitasnya seperti pejabat publik yang dengan kesadarannya mengumumkan ke masyarakat ketika positif Covid-19.

Harian Jogja yang tadinya cukup memberitakan lokasi keberadaan pasien berdasarkan wilayah administrasi kota/kabupaten kemudian mempersempit sampai nama kampung, bahkan wilayah administrasi rukun tetangga (RT), pasien biasa berkaktitivitas dimana juga diuraikan. Kebijakan redaksi ini dimaksudkan memberikan panduan bagi masyarakat agar dapat menghindari wilayah terjangkit atau mendeteksi secara mandiri pernah tidaknya kontak dengan pasien positif sehingga dapat melapor pada petugas kesehatan.

"Kami bisa menyebutkan pasien biasa beraktivitas dimana, walau itu akan mengarah ke identitas, misalnya sering berjualan di pasar, penjual ikan." (Nurcahyo, wawancara, 2020).

Tribun Jogja memiliki pertimbangan lain dalam kebijakan redaksionalnya.
Redaksi menilai penelusuran identitas pasien positif tidak akan banyak membantu. Penyebutan lokasi yang detail bisa semakin mendekatkan korban/ pasien dengan stigma negatif tersebut. Redaksi meyakini dengan memfokuskan pada pemberitaan mengenai langkah- langkah pencegahan dari pemerintah dan pelaksanaanya di masyarakat akan lebih membantu pencegahan penyebaran Covid-19 (Hendy Kurniawan, Manager Produksi Tribun Jogja, wawancara, 20 Januari 2020).

\section{Commercial Consideration dan Political Consideration}

Tribun Jogja dan Harian Jogja tidak melihat commercial considerations dan political consideration sebagai acuan pertimbangan dalam kebijakan redaksionalnya. Bantuan dana darurat ke media terdampak Covid-19, seperti kerjasama 'Ubah Laku' tidak mempengaruhi kebijakan redaksional, di samping itu pemberi bantuan juga tidak ada upaya mengintervensi rutinitas harian di meja redaksi. Bagi Harian Jogja, mengkampanyekan protokol kesehatan agar dapat mengubah perilaku normal baru masyarakat bak lari maraton, sehingga informasi protokol kesehatan perlu ditayangkan secara menerus (Nugroho Nurcahyo, Redatur Pelaksana Harian Jogja, wawancara, 15 Januari 2020). Baik redaksi Tribun Jogja ataupun Harian Jogja melihat kerjasama penayangan berita "Ubah Laku" tersebut mendukung agenda redaksi yang mendorong perubahan perilaku masyarakat di normal baru agar mengurangi penyebaran Covid-19.

Harian Jogja dalam melakukan liputan kolaborasi dengan banyak media lain justru menunjukkan gugurnya pertimbangan kompetisi yang berujung pada faktor komersial, dalam hal merebut perhatian 
audiens. Gans (2004) menegaskan dalam kompetisi, meskipun organisasi berita saling bersaing satu sama lain, petimbangan persaingan tersebut sebagian besar justru berfungsi sebagai bentuk kontrol kualitas. Sementara dalam liputan kolaborasi tersebut, kontrol kualitas dilakukan sejak awal di tangan jurnalis, karena mereka saling berbagi data.

Pada akhirnya, berita tersebut menjadi faktor political consideration untuk memberikan tekanan kepada pemerintahan sebagai pemegang kekuasaan dalam melahirkan kebijakan. Pada faktor ini sekaligus media secara tidak sadar telah mempertahankan faktor pertimbangan nilai (value consideration) bahwa jurnalis dengan produk beritanya untuk mempengaruhi secara persuasif kepada pemangku kepentingan, sebagaimana Gans (2004) menuturkan pertimbangan nilai berfungsi untuk melakukan advokasi.

Dari hasil keseluruhan paparan penelitian, Harian Jogja maupun Tribun Jogja memiliki kebijakan redaksi sesuai dengan karakteristik medianya masingmasing.

Media lokal di Yogyakarta memiliki agenda untuk mengkampanyekan bahaya Covid-19 dan pengetatan protokol kesehatan. Media lokal di Yogyakarta melawan arus utama dari ketidakpastian kebijakan dari pemerintah daerah yang terkesan tidak responsif dengan Covid-19 ketika mulai mewabah di wilayah Pemerintah Provinsi DIY.

Kedua surat kabar harian tersebut juga memiliki kesamaan kebijakan redaksi dalam menempatkan Sri Sultan Hamengku Buwono X, Gubernur DIY sekaligus Raja Keraton Yogyakarta sebagai narasumber dalam pemberitaan. Sultan sebagai narasumber yang memiliki primodial kuat di Yogyakarta tidak selalu menjadi angle utama. Pernyataan- pernyataannya yang kontradiktif dengan situasi pencegahan Covid-19 dihindari. Harian Jogja yang dalam level ekstramedianya terikat dengan kepemilikan saham minoritas GKR Hemas (permaisuri Sultan HB X) di Harian Jogja masih memiliki ruang yang independen dalam pemberitaan Covid-19. Berikut tabel agenda media dan kebijakan redaksional dari kedua media lokal tersebut.

Tabel. 1 Agenda Media dan Kebijakan Redaksional Harian Jogja dan Tribun Jogja dalam berita Covid-19

\begin{tabular}{|c|c|c|}
\hline $\begin{array}{l}\text { Agenda } \\
\text { Media }\end{array}$ & Harian Jogja & Tribun Jogja \\
\hline $\begin{array}{l}\text { Ancaman } \\
\text { penyebaran } \\
\text { Covid-19 } \\
\text { meluas }\end{array}$ & $\begin{array}{l}\text { Memprioritaskan } \\
\text { pakar/ pengamat }\end{array}$ & $\begin{array}{l}\text { Memprioritas } \\
\text { kan pakar } \\
\text { pengamat }\end{array}$ \\
\hline $\begin{array}{l}\text { Pengetatan } \\
\text { Protokol } \\
\text { Kesehatan }\end{array}$ & $\begin{array}{l}\text { - 'Menakut-nakuti' } \\
\text { masyarakat yang } \\
\text { cenderung tidak } \\
\text { percaya Covid-19 } \\
\text { - Mendorong } \\
\text { masyarakat untuk } \\
\text { bekerja dari } \\
\text { rumah. }\end{array}$ & $\begin{array}{l}\text { Mengangkat } \\
\text { people stories, } \\
\text { cerita kesedihan } \\
\text { untuk } \\
\text { membangkitkan } \\
\text { empati, } \\
\text { sehingga } \\
\text { masyarakat } \\
\text { tersadar } \\
\text { protokol } \\
\text { kesehatan. }\end{array}$ \\
\hline $\begin{array}{l}\text { Mendorong } \\
\text { PSBB }\end{array}$ & $\begin{array}{l}\text { Mengesampingkan } \\
\text { dampak ekonomi di } \\
\text { tengah } \\
\text { ketidakjelasan } \\
\text { Pemda DIY }\end{array}$ & $\begin{array}{l}\text { Memaparkan } \\
\text { konsekuensi } \\
\text { baik buruknya } \\
\text { PSBB }\end{array}$ \\
\hline $\begin{array}{l}\text { Perlindung } \\
\text { an privasi } \\
\text { pasien dan } \\
\text { pengegahan } \\
\text { penyebaran } \\
\text { Covid-19 }\end{array}$ & $\begin{array}{l}\text { Mempersempit } \\
\text { identitas hingga } \\
\text { tingkat RT atau } \\
\text { memberikan atribusi } \\
\text { pasien tanpa } \\
\text { menyebut nama. }\end{array}$ & $\begin{array}{l}\text { Penelusuran } \\
\text { identitas pasien } \\
\text { positif tidak } \\
\text { akan banyak } \\
\text { membantu } \\
\text { pencegahan. }\end{array}$ \\
\hline $\begin{array}{l}\text { Keterbuka } \\
\text { an informasi } \\
\text { penyebaran } \\
\text { Covid-19 } \\
\text { sebagai } \\
\text { langkah } \\
\text { pencegahan. }\end{array}$ & $\begin{array}{l}\text { Liputan kolaborasi } \\
\text { antar media }\end{array}$ & $\begin{array}{l}\text { Fokus dengan } \\
\text { people stories }\end{array}$ \\
\hline
\end{tabular}

\section{PENUTUP}

\section{Kesimpulan}

Kebijakan redaksi menentukan keberhasilan media massa sebagai pilar keempat demokrasi dalam mengawal kebijakan pemerintah, dalam hal ini terkait pencegahan Covid-19. 
Story selection yang dilakukan Harian Jogja dan Tribun Jogja memilki penekanan yang berbeda. Pada aspek source consideration, Harian Jogja dan Tribun Jogja memilah sesuai dengan agenda media mereka. Sri Sultan Hamengku Buwono X sebagai gubernur pemerintahan dan tokoh budaya di Yogyakarta bukan lagi menjadi aktor utama ketika kebijakannya dinilai tidak sesuai dengan pencegahan Covid-19.

Harian Jogja dan Tribun Jogja menilai bukan berarti pemerintah daerah tidak peduli dengan Covid-19, tetapi lebih melihat adanya ketidaksiapan dalam mitigasi penyebaran Covid-19, sementara masyarakat banyak yang tidak percaya dengan Covid-19. Melihat situasi tersebut, kedua media lokal Yogyakarta tersebut tidak bisa tinggal diam atau sekadar menunggu agenda kebijakan dari pemerintah daerah. Pada aspek story selection lainnya, Harian Jogja terlihat lebih mencari peluang- peluang baru dalam menyajikan cerita, diantaranya ketika memberika atribusi identitas pasien positif hingga level administrasi RT.

Hal menarik lainnya ketika Harian Jogja memilih untuk melakukan liputan kolaborasi media. Liputan kolaborasi memberi peluang lebih besar media untuk bisa kritis mengawasi pemerintah.

\section{Saran}

Penelitian selanjutnya bisa dikembangkan dengan melihat isu Covid19 dari perspektif media dalam memberitakan hak privasi pasien positif dalam pencegahan Covid-19. Selain itu, penelitian selanjutnya bisa dikaji bagaimana penerapan liputan kolaborasi antar media dalam situasi krisis, sepertinya hal saat pandemi Covid-19.

\section{UCAPAN TERIMAKASIH}

Penulis mengucapkan banyak terimakasih pada pengelola redaksi jurnal yang membantu menyebarkan gagasan ilmiah ini. Penulis berharap tulisan ini bisa bermanfaat bagi pembaca.

\section{DAFTAR PUSTAKA}

Amali, Syamsiah. 2017. “Analisis Isi Berita Program KOMINFO Pada Surat Kabar Daerah". Jurnal Penelitian Komunikasi dan Opini Publik : 193201

Ali, Shahmir H., et all. 2020. "Trends and Predictors of COVID-19 Information Sources and Their Relationship With Knowledge and Beliefs Related to the Pandemic: Nationwide CrossSectional Study." JMIR Public Health and Surveillance Vol 6 (4).

Buluamang, Yohanes Museng Ola. 2020. "Analisis Pemberitaan Agenda Pembangunan Provinsi NTT dalam Surat Kabar Terhadap Terbentuknya Opini Publik", Jurnal Penelitian Komunikasi dan Opini Publik : 56

Coleman, Renita, Maxwell McCombs, Donald Shaw, and David Weaver. 2009. "Agenda Setting, in The Handbook of Journalism Studies, Karin Wahl-Jorgensen and Thomas Hanitzsch (Eds)." New York, NY: Routledge.

Dewan Pers. 2020. "Siaran Pers Media Diimbau Perhatikan Kode Etik Jurnalistik dalam Liputan virus Corona".

https://www.dewanpers.or.id/assets/do cuments/siaranpers/siaran_Pers.pdf

Gans, Herbert J. 2004. "Deciding What's News: A Study of CBS Evening News, NBC Nightly News, and Time." USA : Northwestern University Press.

Hanief, Lalita, Putri Ayu Hidayatur Rafiqoh, and Bachruddin Ali Akhmad. 2021. "Kebijakan Redaksional Radar Banjarmasin pada Pemberitaan Kasus Covid-19 di Kalimantan Selatan". Jurnal Kajian Jurnalisme Vol 4 (2):134-146.

Hammer, Martin. 2006. "Trading on trust:news agencies, local journalism and local media. Trading on trust, , in 
Local Journalism and Local Media, Making The Local News, Bob Franklin (Eds)." New York, NY: Routledge.

Kovach, Bill, and Tom Rosenstiel, T. 2014. "The elements of journalism". New York, NY: Three Rivers Press.

Lestahulu, Said. 2015. "Peran Media Cetak

Dalam Mengawal Kebijakan Publik di Ambon". Jurnal Penelitian Komunikasi dan Opini Publik Vol 19 (1): 1-15

McCombs, Maxwell \& Marcus Funk a. 2011. "Shaping the Agenda of Local Daily Newspapers: A Methodology Merging the Agenda Setting and Community Structure Perspectives." Mass Communication and Society Vol 14 (6), 905-919.

Pamungkas, Andreas Tri. 2016. "Wajah Pers di Yogyakarta Dalam Memberitakan Penyerangan Lapas Cebongan". Tesis, Universitas Gadjah Mada Yogyakarta.

Reese, Stephen D. 2009. "Managing The Symbolic Arena: The Media Sociology of Herbert Gans in Wissenschaft mit Wirkung (Christina Holtz-Bacha, Gunter Reus, \& Lee Becker (Eds)." GWV Fachverlage GmbH, Wiesbaden: VS Verlag für Sozialwissenschaften.
Setiawan, Lukas Deni. 2014. "Narasumber Anonim dan Berita." Tesis, Universitas Gadjah Mada Yogyakarta.

Sudirman, Lu, \& Miming Utami. 2015. "Analisis Yuridis Terhadap Kebebasan Pers di Indonesia dan Malaysia." Journal of Judicial Review Vol.XVII (1): 1-21

Wahl-Jorgensen, Karin. 2006. "Letters To The Editor In Local and Regional Newspapers: Giving Voice To The Readers, in Local Journalism and Local Media, Making The Local News, Bob Franklin (Eds)." New York, NY: Routledge.

Wibisono, Irawan, Pawito, \& Ismi Dwi Astuti. 2019. "Kebijakan Redaksional Dalam Konvergensi Media." Acta Diurna Vol 5 (1): 1-16

William, Granville. 2006. "Profits Before Product? Ownership and Economic of The Local Press, in Local Journalism and Local Media, Making The Local News, Bob Franklin (Eds)." New York, NY: Routledge.

Zhao, Erfei, et.all. 2020. "Media trust and Infection Mitigating Behaviours During The Covid-19 Pandemic in the USA." BMJ Global Health, Vol 5 (10): $1-10$. 